\title{
Metrical Positions and their Linguistic Realisations in Old Germanic Metres: A Typological Overview
}

\section{Seiichi Suzuki*}

\begin{abstract}
This paper provides a typological account of Old Germanic metre by investigating its parametric variations that largely determine the metrical identities of the Old English Beowulf, the Old Saxon Heliand, and Old Norse eddic poetry (composed in fornyrðislag, málaháttr, or ljóðaháttr). The primary parameters to be explored here are the principle of four metrical positions per verse and the differing ways in which these constituent positions are aligned to linguistic material. On the one hand, the four-position principle works with a maximal strictness in Beowulf, and to a slightly lesser extent in fornyrðislag, whereas it allows for a wider range of deviations in verse size in the Heliand and ljóðaháttr. In málaháttr, however, the principle in itself gives way to the five-position counterpart. On the other hand, the variation in the metricallinguistic alignment in the three close cognate metres may be generalised by positing the common scale, Heliand $>$ Beowulf $>$ fornyrðislag, for the decreasing likelihood of resolution, the increasing likelihood of suspending resolution, and the decreasing size of the drop.
\end{abstract}

Keywords: Old Germanic metre, metrical positions, typology, Beowulf, Heliand, fornyrðislag, málaháttr, ljóðaháttr

\section{Introduction: the metrical position as a minimal constituent of a verse}

It was Cable (1974: 84-93) among other metrists who brilliantly brought to light the primacy of metrical positions (or members) as foundational units of Old English alliterative verse: he laid out the arrangement of four metrical positions as the fundamental principle of verse composition in Old English. Indeed, Sievers (1893: 25) had earlier rightfully conceptualised this unit (Glieder) as the smallest metrical constituent, but he failed to fully work out its implications to the logical conclusion (Cable 1974: 32), which Cable accomplished with admirable clarity. By addressing the grouping of these smallest constituents into feet, Sievers obscured, rather than clarified, their primary status in the metre

\footnotetext{
* Author's address: Seiichi Suzuki, Kansai Gaidai University, 16-1 Nakamiyahigashino, Hirakata 573-1001, Japan. E-mail: ssuzuki@kansaigaidai.ac.jp.
} 
(Cable 1974: 91). Thus, Cable (1974) firmly laid the foundation for Old English (and Old Germanic by implication) metrics by his articulate formulation of the principle of four positions as its ultimate basis of versification.

The principle of four metrical positions, however, differs in its exact manners of execution from one metre to another in the Old Germanic alliterative traditions: it prescribes versification with varying strictness and flexibility. Moreover, the principle is replaced in some metres by an expanded version, one of five positions. Beside the number of constituent positions specified, their identities can be different: while a binary opposition between lift $(/)$ and drop $(x)$ prevails, a further distinction between normal $(x)$ and heavy $(\backslash)$ drops may be of significant metrical value to a differing extent. The principle of four positions is accordingly involved in parametric variations along a number of attributes, thereby accounting for the variability of Old Germanic metres in no small measure (section 2).

The metrical position is postulated as an abstract invariant unit underlying a host of linguistic realisations which vary widely along a wealth of parameters including stress, syllable length and number, and lexical properties. Equipped with this underlying unit, then, we are principally concerned with the differing ways in which the metrical position is aligned to various language materials by versification. In other words, the central issues of Old Germanic metrics are to account for the range and likelihood of legitimate linguistic realisations of a given metrical position according to context. Thus, the varying alignments of metrical positions to language materials serve as significant parameters along which individual cognate metres differ in the evolution of Old Germanic versification (section 3 ).

Drawing on the analytical framework outlined above, we will provide a typological survey of the organisation of Old Germanic metres in their structural foundations. Of central concern will be the three major metrical traditions: Beowulf (Beo; Old English; Fulk et al. 2008), the Heliand (Hel; Old Saxon; Behaghel, Taeger 1996), and the three eddic metres (Old Norse; Neckel, Kuhn 1983) - fornyrðislag, málaháttr, and ljóðaháttr. ${ }^{1}$ The primary purpose of this paper, then, is to offer a typological overview, rather than detailed explanatory accounts. It should be noted in parenthesis that the notion of typology just

\footnotetext{
1 The following abbreviations will be used in citation for selected pieces of eddic poetry: Vsp (Volospá; fornyrðislag), Hav (Hávamál; ljóðaháttr), Prk (Prymsqviða; fornyrðislag), Vm (Vafðrúðnismál; ljóðaháttr), Skm (For Scírnis; ljóðaháttr), Hym (Hymisqviða; fornyrðislag), Ls (Locasenna; ljóðaháttr), Vkv (Volundarqviða; fornyrðislag), HH (Helgaqviða Hundingsbana in fyrri; fornyrðislag), HHv (Helgaqviða Hiqrvarðzsonar; fornyrðislag and ljóðaháttr), HH II (Helgaqviða Hundingsbana Qnnor; fornyrðislag), Gðr I (Guðrúnarqviða in fyrsta; fornyrðislag), Sg (Sigurðarqviða in scamma; fornyrðislag), Am (Atlamál in Gronlenzco; málaháttr), Rp (Rígspula; fornyrðislag). For details on the textual basis of the corpus, see Suzuki (2014: 1-5).
} 
mentioned concerns not so much the one of metres from a universal perspective (e.g., Lotz 1960; Wimsatt 1972; Fabb, Halle 2008; Aroui, Arleo 2009), as the localised one in a strictly Old Germanic context. In this sense, the notion corresponds to the archaeologists' use, rather than the linguists': for example, the typology of Anglo-Saxon button brooches (Suzuki 2008) or that of gold bracteates in the Migration Period (Axboe 2004; Behr 2011).

\section{Variation on the principle of four metrical positions in Old Germanic metre}

\subsection{The verse size}

While the principle of four metrical positions - itself being stochastic, rather than categorical, in nature - largely serves as a foundation for verse composition in Old Germanic, the exact status of the principle varies from metre to metre in its binding force, namely, the extent to which it tolerates deviations from the prescription it lays out.

There are two kinds of verses inherent in Old Germanic metre which may potentially count as larger in size than is prescribed by the principle of four metrical positions per verse: verses extended with anacrusis on the one hand (e.g., Beo 758a; see [1] below), and type $\mathrm{D}^{*}(/ \times / \times \times)$ - or its variants, types $\mathrm{D}^{\star} 1(/ \times / \times \times), \mathrm{D}^{\star} 2 \mathrm{a}\left((/ \times / / \times)\right.$, and $\mathrm{D}^{\star} 2 \mathrm{~b}((/ \times / \times))$ in Beowulf (Suzuki 1996: 103-112; e.g., Beo 1749a; see [1] below) - on the other, which is expanded with an additional drop standing between the otherwise consecutive lifts in type $\mathrm{D}(/ / \times \times)$ - or its variants, types D1 $(/ / \times \times)$, D2a $(/ / \mid \times)$, and D2b $(/ / \times \mid)$ in Beowulf (Suzuki 1996: 95-103). In addition, these two expansions can be conjoined, resulting in still longer verses that could be regarded as consisting of six positions (e.g., Beo 2936a; see [1] below):

(1) Beo 758a Gemunde pā se gōda 'Then the good man remembered' $[\mathrm{xPxxxPx}]^{2}$ (type $\mathrm{A} 1$ with anacrusis)

Beo 1749a gȳtsað gromhȳdig 'he covets angry-minded' [PxPSx] (type $\mathrm{D}^{\star} 2 \mathrm{a}$ )

Beo 2936a Besæt đã sinherge 'He then besieged with a huge army' [xPxPs] (type $\mathrm{D}^{\star} 2 \mathrm{a}$ with anacrusis)

$2 \quad \mathrm{P}$ = primary-stressed long syllable; $\mathrm{p}$ = primary-stressed short syllable; $\mathrm{S}=$ secondarystressed long syllable; $\mathrm{s}=$ secondary-stressed short syllable; $\mathrm{x}=$ unstressed syllable, long or short; \# = word boundary (specifically marked in limited contexts). 
Given this range of variability, we have three parameters at hand by means of which we can differentiate the varying strictness of the principle of four metrical positions: (i) the incidence of anacrusis; (ii) the occurrence of type $\mathrm{D}^{*}$ relative to type D; (iii) a combination of (i) and (ii), namely, the expansion of type $\mathrm{D}^{\star}$ with anacrusis. ${ }^{3}$

Since the realisation of anacrusis by prefixes does not constitute an autonomous metrical position in Beowulf (Suzuki 1996: 337-340), and since prefixes are lost for the most part in Old Norse (Noreen 1970: 135; Russom 1998: 14, 209; Suzuki 2014: 174), prefixes cannot serve as a proper indication of the extent to which the principle of four positions per verse tolerates composition of overlong verses in terms of the number of constituent verses. Accordingly, anacrusis as realised by nonprefixal material, that is, independent words - as exemplified in (2) below - is the key to understanding these apparently overlong verses. As it turns out, anacrusis is more likely to occur in fornyrðislag than in Beowulf, insofar as it is realised by an independent word $(\mathrm{p}=0.002$ by Fisher's exact test; ${ }^{4}$ Suzuki 2014: 175-176; on the remaining, less archaic metres, see below). This significant difference demonstrates that the four-position principle is more tolerant and hence less strict in its organising power in fornyrðislag.

(2) Beo 1987a Hū lomp èow on lāde [xPxxPx] 'How did it turn out to you on the journey' (type A1 with nonprefixal anacrusis)

Gðr I 3.5 hver sagði peira 'each said of their' [xPxPx] (type A1 with nonprefixal anacrusis)

Fornyrðislag's greater susceptibility to anacrusis in overall terms is also substantiated by the analogous property of type $\mathrm{A} 1$, by far the most frequent verse type that yields to anacrusis. As indicated in Table 1, type A1 receives anacrusis

3 Catalexis, that is, the composition of apparently three-position verses on the surface (e.g., Sg 30.7 giallan grát 'loud weeping' [PxP]), keeps the verse-final drop intact in underlying representation (Suzuki 2014: 185-201); accordingly, type A1- (Px...P), the catalectic variant of type A1, should be represented in underlying terms as $/ \times / \times$, exactly the same representation as that of type A1 (Px...Px). On account of the unchanged status in metrical structure, this characteristically Old Norse mode of composition strictly follows the principle of four positions per verse. Constituting simply a marked realisation at the surface level, catalexis may accordingly be defined in terms of metrical-linguistic mapping, namely, the alignment of a verse-final drop to null language material, as will be treated in section 3.2 below. Despite the formal reducibility to the full configurations, however, the catalectic variants will be excluded from consideration in the following examination, as catalexis is unknown to the West Germanic metres.

4 On the use of this statistical test, see Suzuki (2014: 15-17). 
with a higher incidence in fornyrðislag than in Beowulf, with a p-value of 0.037 insofar as the expansion is instantiated by independent words.

With respect to the composition of type $\mathrm{D}^{\star}$ (type $\mathrm{D}^{\star} 1$ in Beowulf; see [3] below), however, the two metres hardly differ in the persistence with which the four-position principle controls verse size: no statistical difference can be ascertained between Beowulf and fornyrðislag in the incidence of the expanded configuration $/ \times / \times \times$ relative to the basic one $/ / \times \times(\mathrm{p}=1$; Table 2$)$. At issue here are the minimal variants $\operatorname{Px} \ldots \operatorname{Pxx}(/ \times / \times \times)$ and PPxx $(/ / \times \times)$ in which the last two positions lack a lexical stress. The heavier forms with a lexical stress, $/ / \backslash \times$ and $/ / \times \backslash-$ distinguished as types D2a and D2b, respectively, from the lighter one, type D1 $(/ / \times \times)$, in the metrical system of Beowulfare categorically qualified on prosodic grounds for being expanded to types $\mathrm{D}^{\star} 2 \mathrm{a}$ and $\mathrm{D}^{\star} 2 \mathrm{~b}$ in Beowulf, as will be discussed shortly. The corresponding configurations in fornyrðislag, however, cannot be categorised as analogously distinct from the lighter one. This structural disparity accordingly leaves us with the minimal forms Px...Pxx and PPxx that may yield to a direct comparison between the two metres on a commensurate basis.

(3) Beo 1840b him on andsware 'to him in answer' [PxPxx] (type $\left.\mathrm{D}^{\star} 1\right)$ Vkv 23.1 Snemma kallaði 'Early (he) called’ [PxPxx] (type $\mathrm{D}^{*}$ )

Furthermore, Beowulf and fornyrðislag are indistinguishable on statistical grounds when it comes to the implementation of anacrusis on type $\mathrm{D}^{*}$, namely, the occurrence of the minimal variant of type $\mathrm{D}^{\star}$ with anacrusis in which neither the penultimate nor the final drop is stressed $(\times / \times / \times \times$; Table 3$)$. While Beowulf attests a single instance of type $\mathrm{D}^{\star} 1$ with anacrusis (Beo 2093a Tō lang ys tō reccenne 'It is too long to tell') among the population of twentythree type $\mathrm{D}^{\star} 1$ verses, fornyrðislag gives no occurrences of the corresponding configuration in the forty-seven examples of type $\mathrm{D}^{*}(\mathrm{p}=0.329)$.

Overall, then, Beowulf maximally adheres to the principle of four metrical positions per verse owing to the rigorous rule-governedness to which anacrusis and type $\mathrm{D}^{*}$ are subject in phonological and morphological terms. While fornyrðislag is nearly as faithful, Beowulf may be characterised as slightly more conforming to the principle of four positions, as evidenced by the lesser tolerance of nonprefixal anacrusis, which must constitute a separate position even in Beowulf in defiance of the principle and in contrast to the parasitic prefixal anacrusis.

When all variants of type $\mathrm{D}^{\star}$ are taken into account, however, a radically different picture apparently emerges (Table 4): Beowulf is more likely to be affected by anacrusis than fornyrðislag, with a p-value of 0.002 . At first glance, type $\mathrm{D}^{*}$ 's higher likelihood of undergoing anacrusis in Beowulf might seem 
hardly compatible with the above conclusion that this metre maximally adheres to the four-position principle. Implementing anacrusis on type $\mathrm{D}^{*}$ would result in a maximal deviation from the principle by creating a six-position, rather than a five-position, verse. On closer consideration, however, this apparent contradiction proves to be far from genuine. Corresponding to the organisation of type $\mathrm{D}^{*}$, the configurations subsumed under type $\mathrm{D}$ in fornyrðislag actually fall into three variants in Beowulf, types D1 (/ / × ×; Beo 345b min ärende 'my errand'), D2a (/ / × × e.g., Beo 2582a wearp woelfȳre 'he threw deadly fire'), and D2b (/ / × I; e.g., Beo 1155a eal ingesteald 'all house-property'). The latter two types are distinguished from the former by the presence of a heavy drop $(\backslash)$ as opposed to a normal one $(x)$, either in penultimate or verse-final position. By virtue of this extra prominence involved, the first lift of types D2a and D2b is eligible to be expanded by encliticisation, which results in its extended alignment to a syllable sequence of a primary-stressed syllable and the following unstressed material (Px...; Suzuki 1996: 24-35). Put another way, the first lift of types D2a and D2b is matched with the domain of the phonological phrase (Suzuki 1996: 27-30; compare Anderson 2011: 2008; Revithiadou 2011: 1205) or of the clitic group (compare Nespor, Vogel 1986: 145-163; Hayes 1989: 207-211), with the result that the following unstressed syllables subordinate to the preceding host do not count as autonomous positions. Furthermore, as noted above, the anacrusis realised by prefixes or the negative adverb ne does not constitute a separate metrical position in Beowulf on account of procliticisation (compare OE nis 'is not' < ne 'not' + is 'is'). In fact, a total of seventeen instances of anacrustic types $\mathrm{D}^{\star} 2 \mathrm{a}$ and $\mathrm{D}^{\star} 2 \mathrm{~b}$ are all involved in prefixal anacrusis. ${ }^{5}$ Excluding the prefixal anacrusis from the count, then, we encounter the lack of significant difference between Beowulf and fornyrdislag in regard to the probability with which anacrusis operates on type $\mathrm{D}^{*}$ in general $(\mathrm{p}=1$; Table 4$)$.

Brought together, since neither of the two modes of expansion at issue incurs an addition of an autonomous metrical position in Beowulf, their clustering does not lead to an expansion of a verse in terms of constituent positions. Therefore, we must concentrate on the occurrence of type $\mathrm{D}^{\star} 1$ with anacrusis - the type without a heavy drop $(x / / \times x)$ - in determining the vulnerability of the fourposition principle in Beowulf. In this respect, Beowulf is no more susceptible to the combined implementation of anacrusis and type $\mathrm{D}^{*} 1$ formation than to either of the operations implemented separately. Specifically, there is no significant difference in evidence between anacrusis on type $\mathrm{D}^{\star} 1$ and nonprefixal anacrusis on type $\mathrm{A} 1$ ( $\mathrm{p}=0.140$; Tables 1 and 3$)$, and between anacrusis on

5 Beo 94a, 723a, 772a, 1027a, 1274a, 1451a, 1453a, 1460a, 1543a, 1610a, 1837a, 2044a, 2252a, 2367a, 2738a, 2756a, 2936a. 
type $\mathrm{D}^{\star} 1$ and derivation of type $\mathrm{D}^{\star} 1$ from type $\mathrm{D} 1(\mathrm{p}=0.336$; Tables 1 and 2$)$. Accordingly, we can sustain the conclusion arrived at earlier that Beowulf obeys the four-position principle with a slightly greater fidelity than fornyrðislag.

Table 1 . Occurrences of type aA1 $(x / \times / \times)$ relative to type $A 1(/ \times / \times)$

\begin{tabular}{|l|c|c|c|}
\hline & $\times / \times / \times$ & $/ \times / \times$ & Total \\
\hline Beowulf & $44(2.04 \%)$ & $2111(97.96 \%)$ & $2155(100 \%)$ \\
\hline Beowulf (nonprefixal) & $13(0.61 \%)$ & $2111(99.39 \%)$ & $2124(100 \%)$ \\
\hline Fornyrðislag & $26(1.23 \%)$ & $2092(98.77 \%)$ & $2118(100 \%)$ \\
\hline Heliand & $1105(26.91 \%)$ & $3001(73.09 \%)$ & $4106(100 \%)$ \\
\hline Ljóðaháttr (a-/b-verse) & $84(21.37 \%)$ & $309(78.63 \%)$ & $393(100 \%)$ \\
\hline Málaháttr & $79(76.70 \%)$ & $24(23.30 \%)$ & $103(100 \%)$ \\
\hline
\end{tabular}

Table 2. Occurrences of Px...Pxx $(/ \times / \times x)$ relative to $\operatorname{PPxx}(/ / \times x)$

\begin{tabular}{|l|c|c|c|}
\hline & $/ \times / \times \times$ & $/ / \times \times$ & Total \\
\hline Beowulf & $52(13.20 \%)$ & $342(86.80 \%)$ & $394(100 \%)$ \\
\hline Fornyrðislag & $26(13.00 \%)$ & $174(87.00 \%)$ & $200(100 \%)$ \\
\hline Heliand (minimal variant) & $76(35.68 \%)$ & $137(64.32 \%)$ & $213(100 \%)$ \\
\hline Heliand (all variants) & $465(61.18 \%)$ & $295(38.82 \%)$ & $760(100 \%)$ \\
\hline Ljóðaháttr (minimal variant; a-/b-verse) & $26(86.67 \%)$ & $4(13.33 \%)$ & $30(100 \%)$ \\
\hline Ljóðaháttr (all variants; a-/b-verse) & $143(92.86 \%)$ & $11(7.14 \%)$ & $154(100 \%)$ \\
\hline Málaháttr & $23(82.14 \%)$ & $5(17.86 \%)$ & $28(100 \%)$ \\
\hline
\end{tabular}

Table 3. Occurrences of type $\mathrm{aD}^{*}$ relative to type $\mathrm{D}^{*}$ with a focus on their minimal variants $\times / \times / \times \times$ and $/ \times / \times \times$

\begin{tabular}{|l|c|c|c|}
\hline & $\times / \times / \times \times$ & $/ \times / \times \times$ & Total \\
\hline Beowulf & $1(4.35 \%)$ & $22(95.65 \%)$ & $23(100 \%)$ \\
\hline Fornyrðislag & $0(0 \%)$ & $47(100 \%)$ & $47(100 \%)$ \\
\hline Heliand & $36(32.14 \%)$ & $76(67.86 \%)$ & $112(100 \%)$ \\
\hline Ljóðaháttr & $2(7.14 \%)$ & $26(92.86 \%)$ & $28(100 \%)$ \\
\hline Málaháttr & $0(0 \%)$ & $23(100 \%)$ & $23(100 \%)$ \\
\hline
\end{tabular}

Table 4. Occurrences of type aD* relative to type $\mathrm{D}^{*}$ (all variants)

\begin{tabular}{|l|c|c|c|}
\hline Metre & Type aD & Type D* & Total \\
\hline Beowulf & $18(11.25 \%)$ & $142(88.75 \%)$ & $160(100 \%)$ \\
\hline Beowulf (nonprefixal) & $1(0.70 \%)$ & $142(99.30 \%)$ & $143(100 \%)$ \\
\hline Fornyrðislag & $0(0 \%)$ & $67(100 \%)$ & $67(100 \%)$ \\
\hline Heliand & $212(31.31 \%)$ & $465(68.69 \%)$ & $677(100 \%)$ \\
\hline Ljóðaháttr & $16(10.06 \%)$ & $143(89.94 \%)$ & $159(100 \%)$ \\
\hline Málaháttr & $11(6.01 \%)$ & $172(93.99 \%)$ & $183(100 \%)$ \\
\hline
\end{tabular}


While Beowulf and fornyrðislag are only minimally differentiated in the extent to which the principle of four positions per verse is compromised, the Heliand and ljóðaháttr (a-/b-verse) make a conspicuous difference in this respect from the former two metres. ${ }^{6}$ First, anacrusis is more likely to occur in the Heliand and ljóðaháttr than in Beowulf and fornyrðislag: each of the first group differs significantly from each of the other with a p-value of less than 0.001 (Table $1)$. The Heliand in turn is distinguished from ljóðaháttr by the greater propensity for anacrusis $(\mathrm{p}=0.017)$. Second, as with the incidence of anacrusis, the proportion of type $\mathrm{D}^{*}$ to type $\mathrm{D}$ is significantly higher in the Heliand and ljóðaháttr than in Beowulf and fornyrðislag ( $\mathrm{p}<0.001$; Table 2). Furthermore, contrary to the likelihood of anacrusis, ljóðaháttr displays a greater preference for type $\mathrm{D}^{\star}$ than the Heliand ( $\mathrm{p}<0.001$ ). Given that the privileged association between anacrusis and prefixes is unique to Beowulf, and that the opposition between normal and heavy drops in type $\mathrm{D}$ is no less an exclusive privilege of Beowulf, the greater susceptibility to anacrusis on the one hand and to the composition of type $\mathrm{D}^{*}$ on the other justifies our characterising the fourposition principle as less compelling in the Heliand and ljóðaháttr.

In summary, the Heliand verse is more likely than the ljóðaháttr to be expanded by anacrusis; by contrast, the ljóðaháttr is more likely to be expanded by the extra syllable of type $\mathrm{D}^{*}$. We are thus confronted with the apparently conflicting pattern, whereby the two metres are organised divergently along the two parameters - anacrusis and type $\mathrm{D}^{*}$. In this light, we need a closer inspection of ljóðaháttr, because unlike other metres, ljóðaháttr makes a categorical distinction between the a-verse and the b-verse in terms of the verse types that they are capable of accommodating (Suzuki 2014: 646). Specifically, the a-verse is largely limited to the configurations that begin with a lift, namely, classes A, D, and $\mathrm{E}$. By contrast, the b-verse displays a marked preference precisely for those forms that tend to be excluded by the a-verse, that is, the configurations that begin with a drop, namely, classes B, C, and anacrustic verses of classes A, D, and E. ${ }^{7}$ This complementary distribution of verse types predicated on the distinction between the a-verse and the b-verse would have significant consequences on

\footnotetext{
6 We will exclude the ljóðaháttr c-verse from consideration (except in connection with the contrast with the a-/b-verse in the way marked verse types are accommodated; see section 2.2 below), as it is categorically longer than is prescribed by the four-position principle, and organised on a different formal basis (Suzuki 2014: 665-760).

Admittedly, however, the small sample of class D attested in the corpus - six nonanacrustic a-verses vs. five nonanacrustic b-verses; one anacrustic a-verse vs. four anacrustic b-verses lacks a statistical significance ( $\mathrm{p}=0.308$ ), despite the distribution pattern that is apparently comparable to those of classes $\mathrm{A}$ and $\mathrm{E}$.
} 
operation of anacrusis in ljóðaháttr: anacrusis tends to be avoided in the a-verse, and conversely to be promoted in the b-verse. The overall consequence of this trade-off is that anacrusis is as unlikely to be maximally implemented as to be fully suppressed in ljóðaháttr. More specifically, anacrusis is bound to fall short of its maximal operation, since the major source for anacrusis, type A1, occurs with by far the highest incidence in the a-verse, which is largely incompatible with the occurrence of a drop in verse-initial position. Such a unique complementary organisation of verse types on the basis of the dichotomy into the a-verse and the b-verse may provide an explanatory account of why anacrusis occurs less frequently in ljóðaháttr than in the Heliand, in which favorable conditions for anacrusis may apply pervasively to the whole set of verses without demonstrable distinction between the a-verse and the b-verse. Also subject to the same account is the markedly lower frequency in ljóðaháttr of type $\mathrm{aD}^{*}$ relative to type $\mathrm{D}^{*}$ than in the Heliand, with a p-value of less than 0.001 : the failure to implement anacrusis pervasively in ljóðaháttr renders the composition of type $\mathrm{aD}^{\star}$ less likely than in the Heliand.

Having identified the specific factor - the opposition between the verseinitial lift and the verse-initial drop - that subverts maximal implementation of anacrusis in ljóðaháttr, we might also be required to reexamine the occurrence of type $\mathrm{D}^{\star}$ relative to type $\mathrm{D}$ by contextualising it in relation to the opposition between the a-verse and the b-verse. Since types $\mathrm{D}$ and $\mathrm{D}^{*}$ are indistinguishable from each other in verse-initial position in contrast to the structural opposition between the basic and anacrustic variants in this respect, however, the factor in question has no immediate bearing on the relation between the two types. Therefore, we can maintain the above observation on the larger presence of type $\mathrm{D}^{*}$ in ljóðaháttr than in the Heliand as a significant generalisation: the minimal variant of the expanded type is more likely to occur in ljóðaháttr than in the Heliand with a p-value of less than 0.001; no less remarkably, type $\mathrm{D}^{*}$ in all its manifestations appears with a significantly greater incidence in ljóðaháttr $(\mathrm{p}<0.001)$. We may accordingly be justified in inferring with confidence that ljóðaháttr's greater preference for type $\mathrm{D}^{*}$, rather than its lower incidence of anacrusis, reflects more transparently the relative prescriptive force of the four-position principle in verse composition. Therefore, we may conclude that the four-position principle is less demanding and more flexible in ljóðaháttr than in the Heliand.

To recapitulate the varying degrees of rigour with which the four-position principle determines versification, we may posit the following scale in order of decreasing control over verse size:

(4) Beowulf $>$ fornyrðislag $>$ Heliand $>$ ljóðaháttr 
Finally, the four-position principle gave way to an alternative generalisation in málaháttr: it was replaced by the principle of five metrical positions (Suzuki 2014: 467-469). ${ }^{8}$ In other words, the verse was expanded in málaháttr through an addition of a drop: the verse comprises two lifts and three drops. Concomitantly, anacrusis was reconstituted as a virtually mandatory means of supplying a required fifth position, particularly for the minimal variant of type A1 (Px\#Px; e.g., Am 53.3 ótto alla 'all dawn'; Suzuki 2014: 441-445). As a consequence, type aA1 (e.g., Am 5.2 oc elda kyndo 'and kindled fire') figures centrally at the expense of type A1 contrary to the other metres, in which the anacrustic variant stands on the margin (Table 1). By the same token, type $\mathrm{D}^{*}$ (e.g., Am 94.2 manna tíginna 'of noble men') overwhelmingly occurs to the detriment of type D (e.g., Am 102.3 hluti hvárigra 'the fate of each of two') because of its full conformity to the five-position principle (Table 2).

Of further importance is the proportion of type $\mathrm{D}^{*}$ with anacrusis to the nonanacrustic counterpart (all variants; Table 4). Given the difference in the canonical number of metrical positions in a verse, it seems only natural that type $\mathrm{D}^{*}$ with anacrusis should be used more frequently in málaháttr than in any other metre: consisting of six positions, the anacrustic variant of type $\mathrm{D}^{*}$ counts as less removed in size from the five-position canon than from the four-position one; therefore, it should be most likely to appear in málaháttr among all of the metres under consideration. ${ }^{9}$

As it turns out, however, type $\mathrm{D}^{*}$ is much more amenable to anacrusis in the Heliand than in málaháttr ( $\mathrm{p}<0.001$; Table 4). The latter in turn ranks higher than Beowulf (nonprefixal; $\mathrm{p}=0.015)$ and fornyrðislag $(\mathrm{p}=0.040)$ in the probability of type $\mathrm{D}^{\star}$ being expanded with anacrusis, fully in accordance with the prediction. This unexpected relative ranking between the Heliand and málaháttr seems all the more striking when we observe that type A1, by far the most productive source for anacrusis, displays an outstandingly greater preference for anacrusis in málaháttr than in the Heliand ( $\mathrm{p}<0.001$; Table 1).

Such a discrepancy in implementation of anacrusis between types A 1 and $\mathrm{D}^{\star}$ may yield to a credible account by assuming that the five-position principle functions with greater vigour in málaháttr than does the four-position counterpart in the Heliand. Inasmuch as implementing anacrusis on type $\mathrm{D}^{\star}$ results in a six-position verse, type $\mathrm{D}^{\star}$ with anacrusis will violate the five-position

8 On other consequences of the introduction of the five-position principle, see Suzuki (2014: 429-434, 452-457, 467-469).

9 Ljóðaháttr may well be disregarded here: in it, implementation of anacrusis is determined in a unique way by the complementarity of the a-verse and the b-verse, as remarked above. 
principle in the same way as does the minimal variant of type A1 without anacrusis (i.e., Px\#Px); while the latter configuration is strongly avoided in málaháttr in favour of the expansion with anacrusis in conformity with the five-position principle as pointed out above, the same verse type receives anacrusis extensively in the Heliand in violation of the four-position canon (Table 1 ); in parallel fashion, type $\mathrm{D}^{\star}$ is more strictly deterred from anacrusis in málaháttr than in the Heliand. The contrast with the Heliand thus confirms our characterising málaháttr as conforming to the verse-making principle with a greater fidelity than the Heliand. Since type $\mathrm{aD}^{\star}$ comprises six positions, the relatively tight control over this oversized configuration would mean that the five-position principle regulates verse composition more vigorously in málaháttr than does the four-position one in the Heliand.

\subsection{The opposition between normal and heavy drops}

Apart from the differing degrees of deviations allowed in terms of the number of constituent positions, the principle may vary in regard to the kind of the positions it licenses in versification. More specifically, the positions are divided into two classes, strong positions or lifts (/) on the one hand, and weak ones or drops on the other. The latter in turn fall into two variants, normal $(x)$ and heavy $(\backslash)$. Usually, the four-position verse consists of two lifts and two normal drops; these prototypical configurations are characterised as basic types. Occasionally, however, heavy drops may occur in place of the normal ones, as in types A2a (/ I/ ×; e.g., Beo 626a wisfoest wordum 'wise in words'), A2b (/ × / / e.g., Beo 1522a grc̄edig gūðlēoð 'greedy war-song'), D2a (/ / \×; see above), and D2b (/ / × \; see above), which are referred to as increased types by virtue of the greater prominence concomitant with the promotion from the normal to the heavy drop.

While Beowulf has thus these four increased types at its disposal, the Heliand has access to only one, namely, the configuration corresponding to type A2b in Beowulf (e.g., Hel 1032a man an mênuuerk 'men on sin'), which should be categorised as type A2 in the absence of its mirror-image opposite, type A2a (Suzuki 2004: 29-30, 66-73, 125-136). In regard to the Norse metres, fornyrðislag and ljóðaháttr maintain the opposition between types A2a (e.g., Vsp 48.7 veggbergs visir 'the princes of the wall-mountain'; Hav 29.4 hraðmoelt tunga 'a quick tongue') and A2b (e.g., Sg 4.3 moeki málfán 'an inlaid sword'; Skm 23.2 mióvan, málfán 'slender, inlaid'; Suzuki 2014: 43-56, 587-590), whereas the one involving types D1, D2a, and D2b is completely lost to be leveled as type D (Suzuki 2014: 110-114, 624-627, 634). Málaháttr is similar to the Heliand in that it has access to only a single increased type, type A2 (e.g., Am 
72.5 geeddi ocr Grímildr 'Grimhild enriched us'; Suzuki 2014: 448-450), corresponding to type $\mathrm{A} 2 \mathrm{~b}$ in the other two Norse metres. ${ }^{10}$

Furthermore, there is the reduced type (type A3; $[\times \times / \times]$; e.g., Beo 1782a $G \bar{a} n \bar{u}$ to setle [xxxPx] 'Go now to the seat'), which emerges in West Germanic through a demotion of the otherwise expected verse-initial lift (as manifested in type A1 $[/ \times / \times]$ ) to a normal drop (Suzuki 1996: 47-59). Inasmuch as both the increased and reduced types are derived through an extra mechanism of transforming the default composition comprising the maximally differentiated positions, two lifts and two normal drops, they must be counted as marked configurations.

These marked verse types - increased or reduced - are distributed differentially between the a-verse and the b-verse, as most eloquently testified in Beowulf (Suzuki 1996: 65-68, 95-110), and somewhat less conspicuously in the Heliand (Suzuki 2004: 66-68, 125-136) and fornyrðislag (Suzuki 2014: 43-56, 110-114). Regardless of the extent of differentiation, it holds generally true that the a-verse is more accommodating: the marked types are more likely to occur in it than in the b-verse on statistical grounds.

Of further interest, ljóðaháttr, which is organised on a radically different basis as pointed out above, displays an analogous contrast between the a-/b-verse and the main body of the c-verse, that is, the whole constituent that precedes the cadence / (Suzuki 2014: 725-739): the a-/b-verse allows a wider range of verse types to appear, whereas the c-verse accommodates only the unmarked configurations. Specifically, while largely displaying the same distribution pattern of verse types as evinced by the a-verse, the c-verse conspicuously diverges from it by the avoidance of types $\mathrm{A} 2 \mathrm{a}, \mathrm{A} 2 \mathrm{~b}, \mathrm{D}^{\star}$, and $\mathrm{E}$. These four types have exclusively in common the property of being more prominent than the basic types: a heavy drop occurs (types A2a, A2b, and E); or five, rather than four, positions are involved (type $\mathrm{D}^{\star}$ ). We are accordingly led to hold the presence of such an extra amount of prominence to be responsible for the c-verse's avoidance of the four types in question: these four constitute precisely the whole set of verse types that are loaded more heavily than the minimal ones with two lifts and two normal drops. ${ }^{11}$ We may then conclude that the c-verse accommodates only verse configurations that comprise normal drops.

10 In addition, the heavy drop occurs as the first drop of type $\mathrm{E}(/ \backslash \times /)$. In the absence of the minimally distinct configuration $/ \times \times /$, however, type $\mathrm{E}$ cannot be identified as an increased type (Suzuki 1996: 121, 135-136).

11 It should be recalled that, represented as $/ / \times \times$, type D does not contain a heavy drop in the Norse metres, in distinction from Beowulf, in which the three configurations $-/ / \times \times$ (type D1), / / $\times($ type D2a), and / / $\times($ type D2b) - are structurally opposed. 
In summary, the four-position principle imposes a stricter constraint on the b-verse than on the a-verse in Beowulf and its immediate cognate metres including fornyrðislag. Similarly, it imposes a stricter constraint on the ljóðaháttr c-verse than on the a-/b-verse. Normal drops are the most privileged to appear, and heavy ones are avoided, in these verses, which may accordingly be characterised as unmarked. ${ }^{12}$

\section{Variation in the alignment of metrical positions to language material}

\subsection{The lift}

\subsubsection{Resolution}

Prototypically, the lift is aligned to a long primary-stressed syllable (P). Less typically, however, it is mapped either to a disyllabic sequence of a short primary-stressed syllable and an unstressed syllable (px) by resolution (Auflösung) or to a short primary-stressed syllable ( $\mathrm{p}$ ) on its own by suspension of resolution. These two marked modes of alignment are implemented differently in individual metres.

Beginning with resolution, as exemplified in (5), we provide an overview of the varying incidence of resolution with reference to the first and the second lift separately (Suzuki 2014: 472-473, 745-751); the first lift is more amenable to the process in general and less susceptible to syntagmatic conditioning than the second.

(5) Resolution on the first lift:

Type A1

Beo 153a fyrene ond fāhðe 'pain and feud' [pxxxPx]

Hel 2091a gumon imu tegegnes 'of men in front of him' [pxxxxPx]

Vsp 47.8 sefi of gleypir 'the kin swallows up' (fornyrðislag) [pxxPx]

Am 26.3 pyti af piósti 'it roared out of fury' (málaháttr) [pxxPx]

Hav 106.4 yfir oc undir 'over and under' (ljóðaháttr) [pxxPx]

\footnotetext{
12 The markedness relation between the a-/b-verse (marked) and the c-verse (unmarked; excluding the cadence /) in ljóðaháttr that is characterised in terms of their relative prominence profile thus proves to be analogous to that between the a-verse (marked) and the b-verse (unmarked) in the other metres. Noteworthy further is the identical linear order involved, marked-unmarked.
} 
Type C

Beo $1188 \mathrm{~b}$ pǣr hyre byre wǣron 'where her sons were' [xxxpxPx]

$\mathrm{Hel} 3655 \mathrm{~b}$ te themu godes barne 'to the Son of God' [xxxpxPx]

HH 1.2 pat er arar gullo 'the eagles screeched' (fornyrðislag) [xxpxPx]

Am 71.4 er vóro sacar minni 'that were lesser causes' (málaháttr) [xxxpxPx]

Grm 35.5 enn á hliðo fúnar 'it decays at the side’ (ljóðaháttr) [xxpxPx]

Resolution on the second lift:

Type A1

Beo 2192a golde gegyrede 'with gold prepared' [Pxxpxx]

Hel 4476a frêson is ferahes 'entrap his life' [Pxxpxx]

Hym 34.5 hóf sér á hǫfuð up 'lifted up on his head' (fornyrðislag) [Pxxpxx]

Am 35.1 Hogni svaraði 'Hogni answered' (málaháttr) [Pxpxx]

Type B

Beo 267a Wē purh holdne hige 'We through loyal mind' [xxPxpx]

$\mathrm{Hel} 5817 \mathrm{~b}$ endi thero uuîbo hugi 'and these women's mind' [xxxxPxpx]

Vm 8.2 nú emc af gǫngo kominn 'now I have come on journey' (ljóðaháttr)

[xxxPxpx]

As shown in Table 5, resolution on the first lift is more likely to occur in the Heliand than in Beowulf in the West Germanic tradition $(\mathrm{p}<0.001)$. As far as the three Norse metres are concerned, fornyrðislag and málaháttr, while indistinguishable from each other $(\mathrm{p}=0.306)$, are more amenable to the process than ljóðaháttr ( $\mathrm{p}<0.001$ between fornyrðislag and ljóðaháttr; p 0.011 between málaháttr and ljóðaháttr). Furthermore, Beowulf as well as the Heliand is subject to resolution with a greater incidence than fornyrðislag $(\mathrm{p}<0.001)$. We may accordingly postulate the following scale for the decreasing likelihood of resolution on the first lift:

(6) Heliand > Beowulf > fornyrðislag/málaháttr > ljóðaháttr

Table 5. Resolution on the first lift

\begin{tabular}{|l|c|c|c|}
\hline Metre & Long & Resolved & Total \\
\hline Beowulf & $5243(72.79 \%)$ & $1090(17.21 \%)$ & $6333(100 \%)$ \\
\hline Heliand & $8836(79.37 \%)$ & $2296(20.63 \%)$ & $11132(100 \%)$ \\
\hline Fornyrðislag & $5269(88.30 \%)$ & $698(11.70 \%)$ & $5967(100 \%)$ \\
\hline Málaháttr & $681(89.61 \%)$ & $79(10.39 \%)$ & $760(100 \%)$ \\
\hline Ljóðaháttr (a-/b-verse) & $1975(92.59 \%)$ & $158(7.41 \%)$ & $2133(100 \%)$ \\
\hline
\end{tabular}


In regard to the second lift (Table 6), too, the four-way division obtains, as illustrated by the following scale, whereby the four groups are differentiated with a p-value of less than 0.001, and fornyrðislag and málaháttr alone are indistinguishable from each other $(\mathrm{p}=0.514)$ :

(7) Heliand > ljóðaháttr > Beowulf > fornyrðislag/málaháttr

Table 6. Resolution on the second lift

\begin{tabular}{|l|c|c|c|}
\hline Metre & Long & Resolved & Total \\
\hline Beowulf & $5016(91.35 \%)$ & $475(8.65 \%)$ & $5491(100 \%)$ \\
\hline Heliand & $8452(81.78 \%)$ & $1883(18.22 \%)$ & $10335(100 \%)$ \\
\hline Fornyrðislag & $5163(99.65 \%)$ & $18(0.35 \%)$ & $5181(100 \%)$ \\
\hline Málaháttr & $749(99.47 \%)$ & $4(0.53 \%)$ & $753(100 \%)$ \\
\hline Ljóðaháttr (a-/b-verse) & $1536(85.19 \%)$ & $267(14.81 \%)$ & $1803(100 \%)$ \\
\hline
\end{tabular}

A notable difference from the first lift is the relatively high frequency of resolution on the second lift in ljóðaháttr, which ranks next to the Heliand. Moreover, only in ljóðaháttr is the second lift more likely to be resolved than the first. This reverse proportion that is unique to ljóðaháttr is contrary to the general pattern predicated on the relative prominence of the two lifts. According to the linearity-based prominence scale, given two positions of the same kind (lifts in this case), the one standing closer to the beginning of a verse counts as more prominent (Suzuki 1996: 167; 2004: 10; 2014: 11); therefore, in overall terms the first lift is loaded with greater prominence than the second one. Since resolution increases prominence by alignment to a disyllable rather than a monosyllable, the inherently more prominent position is more amenable to the process; hence, it may follow that the first lift is resolved with a higher probability than the second one. In this light, ljóðaháttr defies this structurallymotivated, privileged operation of resolution on the first lift.

On closer inspection, the greater incidence of resolution on the second lift in ljóðaháttr turns out to be a local property of the verse-final lift, rather than the second lift in general. As substantiated in Table 7, an overwhelming majority of the resolved second lift in ljóðaháttr is instantiated by the verse-final lift, which occurs exclusively in types B and E. Confronted with the more numerous occurrences of resolution in verse-final position than elsewhere, then, we may generalise that the verse-final lift - the least prominent lift in a verse - constitutes an optimal location for implementation of resolution in ljóðaháttr. Accordingly, ljóðaháttr maximally diverges from the other two Norse metres, which are in turn differentiated from the West Germanic 
cognates by a radically diminished operation of resolution. In other words, the traditional practice of resolution would largely have been disrupted on Scandinavian soil. Given that the virtual loss of resolution in fornyrðislag and málaháttr is phonologically motivated (Russom 1998: 105, 117, 210; Suzuki 2014: 274, 774-775, 793-794), and since ljóðaháttr must have been founded on the same linguistic basis, it may follow that the alignment of the verse-final lift to the disyllable px in the latter metre cannot properly be attributed to the inheritance of the traditional resolution in diachronic terms: this unique mapping would have arisen as an innovation at a relative late stage of the Norse metrical development (for details, see Suzuki 2014: 745-751, 793-794).

The above account receives confirmation when we compare the incidence of resolution on the second lift excluding the verse-final one (Table 8). The three Norse metres are all minimally affected by resolution without a significant distinction: $\mathrm{p}=0.539$ between fornyrðislag and málaháttr; $\mathrm{p}=1$ between fornyrðislag and ljóðaháttr; $\mathrm{p}=0.492$ between málaháttr and ljóðaháttr. We may be led to conclude with added confidence that the inherited resolution would have been weakened in the Norse tradition in general and all but moribund for the second lift in particular. Accordingly, once we have removed the disyllabic realisation of the verse-final lift in ljóðaháttr, we may postulate essentially the same scalar distinction in implementation of resolution for both lifts in the form specified in (6) above: Heliand > Beowulf > fornyrðislag/ málaháttr/ljóðaháttr.

Table 7. Resolution on the second lift depending on verse-finality

\begin{tabular}{|l|c|c|c|}
\hline Metre & Verse-final & Others & Total \\
\hline Beowulf & $111(23.37 \%)$ & $364(76.63 \%)$ & $475(100 \%)$ \\
\hline Heliand & $1097(58.26 \%)$ & $786(41.74 \%)$ & $1883(100 \%)$ \\
\hline Fornyrðislag & $0(0 \%)$ & $18(100 \%)$ & $18(100 \%)$ \\
\hline Málaháttr & $0(0 \%)$ & $4(100 \%)$ & $4(100 \%)$ \\
\hline Ljóðaháttr (a-/b-verse) & $263(98.50 \%)$ & $4(1.50 \%)$ & $267(100 \%)$ \\
\hline
\end{tabular}

Table 8. Resolution on the second lift excluding the verse-final one

\begin{tabular}{|l|c|c|c|}
\hline Metre & Long & Resolved & Total \\
\hline Beowulf & $3670(90.98 \%)$ & $364(9.02 \%)$ & $4034(100 \%)$ \\
\hline Heliand & $5844(88.14 \%)$ & $786(11.86 \%)$ & $6630(100 \%)$ \\
\hline Fornyrðislag & $4569(99.61 \%)$ & $18(0.39 \%)$ & $4587(100 \%)$ \\
\hline Málaháttr & $747(99.47 \%)$ & $4(0.53 \%)$ & $751(100 \%)$ \\
\hline Ljóðaháttr (a-/b-verse) & $1202(99.67 \%)$ & $4(0.33 \%)$ & $1206(100 \%)$ \\
\hline
\end{tabular}




\subsubsection{Suspension of resolution}

The polar opposite of resolution is constituted by suspension of resolution, whereby the lift is aligned to a short stressed syllable. Much as resolution embodies a strengthening of the lift through an expansion in linguistic alignment, its suspension may be characterised as a weakening of the same position through a reduced alignment in prosodic terms. Suspension of resolution affects primarily the following two locations: the second lift of subtype A1s (PS\#px; [8]; a short variant of type A1 - hence, the label A1s - with the short second lift) and the second lift of type $\mathrm{C}(\mathrm{x} . . \mathrm{P \# px}$ [10]) - where $\mathrm{P}=$ a primary-stressed long syllable, $\mathrm{S}=$ a secondary-stressed long syllable, $\mathrm{p}=$ a primary-stressed short syllable, $\mathrm{x}=$ an unstressed syllable, long or short, and \# = a word boundary (as in note 2 above).

(8) Beo 1731b hlēoburh wera 'stronghold of men' [PSpx] $\mathrm{Hel}$ 792a mancraft mikil 'a great crowd of men' [PSpx] HH II 44.8 valdogg sleginn 'with corpse-dew covered' [PSpx] (fornyrðislag) Skm 24.1 Ánauð pola 'coercion endure' [PSpx] (ljóðaháttr)

The configuration PS\#px, the prototypical realisation of subtype A1s, occurs in individual metres with a varying incidence relative to its structural opposites, PS\#pxx (type A2a with the resolved second lift), PS\#Px (type A2a), and Px\#Px (the minimal and prototypical variant of type A1), as represented in Table 9 (compare Suzuki 2014: 246), in which anacrustic realisations are not included. Compared with Beowulf, subtype A1s is marginalised in the Heliand, as substantiated by its much reduced frequency relative to the configurations PS\#Px ( $\mathrm{p}<$ $0.001)$ and $\mathrm{Px} \# \mathrm{Px}(\mathrm{p}=0.016)$. By contrast, subtype A1s figures more prominently in fornyrdislag than in Beowulf, according to the same two parameters ( $\mathrm{p}<0.001$ in either case). Concomitantly, type A2a becomes less vigorous in the Norse metre, much as in the Heliand. In other words, the proportion of the configuration PS\#px to PS\#Px is reversed in the Heliand and fornyrðislag, whereby the second lift is more likely to be realised by a short stressed syllable than by a long one contrary to the pattern in Beowulf: the two metres are hardly distinguishable with respect to the relative occurrence of the two configurations $(\mathrm{p}=0.698)$. What differentiates sharply between the Heliand and fornyrðislag, however, is that while both PS\#px and PS\#Px are relegated to the periphery in the Heliand, only the latter loses in its relative presence; the conspicuous ascendance of the verse form PS\#px may accordingly be regarded as part of fornyrðislag's identity.

As far as the composition of subtype A1s is concerned, the prototypicality of the form PS\#px is largely weakened in fornyrðislag and completely subverted in ljódaháttr. Specifically, the proportion of the originally representative configuration PS\#px to the marginal one Px...px differs between Beowulf and 
fornyrðislag on the one hand ( $\mathrm{p}<0.001)$, and between Beowulf and ljóðaháttr on the other $(\mathrm{p}<0.001)$. Moreover, the two Norse metres are no less sharply distinguished on the same parameter $(\mathrm{p}<0.001)$. Thus, ljóðaháttr stands out by the disruption of the inherited markedness relation whereby the earlier marginal configuration is reorganised as a central variant of subtype A1s and conversely the previous prototypical variant is deprived of its representative status. In light of this reorganisation, the proportion of the configuration PS\#px to type A2a (PS\#Px) in ljóðaháttr seems to be inherited apparently unchanged from Beowulf $(\mathrm{p}=0.344)$. In actuality, however, the large presence of subtype A1s as a whole relative to type A2a makes no difference between the two Norse metres $(\mathrm{p}=0.183)$ : subtype A1s prevails in both. The invigoration of subtype A1s may therefore be characterised as a general property of the Norse metrical tradition. ${ }^{13}$ The four metres are accordingly involved in the following scale in order of decreasing probability of subtype A1s's occurrence:

(9) fornyrðislag/ljóðaháttr > Beowulf > Heliand

As it turns out, the above scale is largely the converse of the one for the likelihood of resolution (6). This complementarity is only natural, given that operation and suspension of resolution are an increase and a decrease, respectively, of prominence on the lift.

Table 9. Occurrences of PS\#px, Pxpx, Px...px, PS\#pxx, PS\#Px, and Px\#Px

\begin{tabular}{|l|c|c|c|c|c|c|}
\hline Metre & PS\#px & PS\#pxx & PS\#Px & Px\#Px & Pxpx & Px...px \\
\hline Beowulf & 59 & 29 & 115 & 877 & 7 & 0 \\
\hline Heliand & 38 & 3 & 9 & 949 & 0 & 0 \\
\hline Fornyrðislag & 158 & 0 & 47 & 1075 & 64 & 18 \\
\hline Málaháttr & 0 & 0 & 0 & 3 & 0 & 0 \\
\hline Ljóðaháttr (a-/b-verse) & 5 & 0 & 18 & 84 & 26 & 29 \\
\hline
\end{tabular}

Turning to the variant of type $\mathrm{C}$ with the short second lift (x...P\#px; see [10] below), we are concerned with its likelihood of occurrence relative to the longer

13 The complete absence of subtype A1s as well as of type A2a in málaháttr has independent motivations. First, neither of the types is compatible with the novel principle of five positions per verse. It may be interesting to point out that málaháttr offers a single instance of subtype A1s, which is expanded with anacrusis, however, in accordance with the new principle (Am 73.3 i kné gengr hnefi 'the trunk collapses'; Suzuki 2014: 444). Second, málaháttr is strictly and pervasively controlled by the canonical cadence Px. Since subtype A1s (and the variant of type $\mathrm{C}, \mathrm{x}$...Ppx, to be treated below) ends in px, this configuration counts as less than optimal and accordingly tends to be avoided. 
variant $(\mathrm{x} . . \mathrm{P \# Px})$. The distribution of these two minimally distinct variants is represented in Table 10 (compare Suzuki 2014: 254). The variant with the resolved first lift (x...px\#Px; see [5] above), which overwhelmingly favors the long second one $(\mathrm{P})$ over the short counterpart $(\mathrm{p})$, is excluded from consideration.

(10) Beo 3014b pā sceall brond fretan 'Then fire shall devour' [xxPpx] Hel 1724b Sulic sint hîr folc manag 'Such people are many here' [xxxxPpx] prk 3.7 ef ec minn hamar 'if I my hammer' [xxPpx] (fornyrðislag) Am 54.5 várom prír tigir 'there were thirty' [xxPpx] (málaháttr) Ls 55.2 hygg ec á for vera 'I think (Thor) being on his way' [ $\mathrm{xxxPpx}$ ] (ljóðaháttr)

Table 10. Occurrences of $x \ldots . . P p x$ and $x \ldots . . P P x$

\begin{tabular}{|l|c|c|c|}
\hline Metre & x...Ppx & x...PPx & Total \\
\hline Beowulf & $261(69.41 \%)$ & $115(30.59 \%)$ & $376(100 \%)$ \\
\hline Heliand & $455(70.98 \%)$ & $186(29.02 \%)$ & $641(100 \%)$ \\
\hline Fornyrðislag & $279(70.81 \%)$ & $115(29.19 \%)$ & $394(100 \%)$ \\
\hline Málaháttr & $5(4.24 \%)$ & $113(95.76 \%)$ & $118(100 \%)$ \\
\hline Ljóðaháttr (a-/b-verse) & $146(73.00 \%)$ & $54(27.00 \%)$ & $200(100 \%)$ \\
\hline
\end{tabular}

As should be clear from the above table, there can be found no significant difference in the incidence of suspending resolution on the second lift of type $\mathrm{C}$ (x...Ppx) in four of the five metres: $\mathrm{p}=0.619$ between Beowulf and the Heliand; $\mathrm{p}=0.694$ between Beowulf and fornyrðislag; $\mathrm{p}=0.388$ between Beowulf and ljóðaháttr; $\mathrm{p}=1$ between the Heliand and fornyrðislag; $\mathrm{p}=0.654$ between the Heliand and ljóðaháttr; $\mathrm{p}=0.631$ between fornyrðislag and ljóðaháttr. The sole exception is málaháttr, which has the proportion of the short to the long second lift reversed in favour of the latter. This unique exceptionality readily yields to a principled explanation: it is due to the ubiquity of the optimal cadence $P x$ in this metre, as pointed out in note 13 above.

Thus, the two primary sources of suspending resolution give partially conflicting pictures. On the one hand, the probability of composing subtype A1s differs significantly: it is maximal in fornyrðislag and ljóðaháttr, and minimal in the Heliand, with Beowulf standing in between. On the other hand, the second lift of type $\mathrm{C}$ is aligned to a short stressed syllable with indistinguishable probabilities in all of the four metres concerned. In other words, while there is no room for variation across individual metres in the likelihood of type $\mathrm{C}$ being suspended from resolution on the second lift, subtype A1s is subject to a significant range of variation in the probability of its occurrence. 
We then encounter the following question: Why are the two configurations differentiated in terms of their variability in occurrence among the four cognate metres? More specifically, why is it that the configuration x...P\#px is used with a constant rate of incidence whereas subtype A1s varies conspicuously across the individual traditions, rather than vice versa? A most plausible answer may be sought in the varying extent to which the suspension of resolution in the two cases is motivated on general prosodic grounds: type $\mathrm{C}$ seems to be founded on invariant surface phonetic motivations. At issue is the clashing of lifts in type $\mathrm{C}$, whereby the second one is eclipsed by the immediately preceding, more prominent position, which renders the following like entity less perceptible in relative terms (compare Sievers 1893: 195, 199; Cable 1974: 65-74; 1991: 29-30; Suzuki 1996: 187-189; 2004: 208-209; 2014: 253-254). These overshadowing effects, then, reduce the viability of implementing the optimal alignment of the second lift to a long stressed syllable. The weakened perceptibility involved accordingly demotes the affected position to be realised by a less salient prosodic unit, namely, a short, rather than a long, stressed syllable. Elaborating on Cable's (1991: 150) insightful observation, the metrical demotion at issue may be viewed as analogous to a variety of downstep in a tone language whereby the second of the two succeeding high tones is lowered (compare Odden 1986: 363-364; Gussenhoven 2004: 104; Connell 2011: 833). ${ }^{14}$ Since the clashing lifts as a substantive motivation for metrical readjustment should equally arise as a surface prosodic phenomenon irrespective of the underlying organisation of individual metres, suspension of resolution is naturally practiced for type $\mathrm{C}$ without a notable dialectal distinction.

By contrast, the motivation for the composition of subtype A1s is of a different nature: it is deeply embedded into the inner metrical organisation, rather than being prompted as a natural reaction to the phonetic given of clashing lifts. Subtype A1s constitutes a marked variant of type A1 which is produced by a special mechanism of derivation (for details, see Suzuki 1996: 81-89). Instead of aligning the second lift to a long (i.e., bimoraic) stressed syllable as is normally executed, it is secondarily associated with the second mora of the preceding drop, in addition to its immediate alignment to a short (i.e., monomoraic) stressed syllable (p). By such a double alignment to the

\footnotetext{
14 Alternatively, where the second of the two clashing lifts is realised by a long stressed syllable (P), as opposed to a short one (p) through suspension of resolution, the first counterpart is promoted in prominence through alignment to a disyllable (px) by resolution, resulting in the configuration $\mathrm{x}$...pxPx. This option may be compared to upstep or a high tone raising, that is, a tonal mechanism whereby one of the two succeeding high tones, or a high tone preceding a low one, is raised as a result of contrast enhancement (Gussenhoven 2004: 108-110; Connell 2011: 834-836).
} 
two consecutive segments, the second lift is counted properly as bimoraic in accordance with the bimoraicity requirement otherwise breached. The motivation for this marked derivation is highly structure-dependent, and hence may readily be susceptible to reorganisation from metre to metre, depending in no small measure on the linguistic environment.

As evidenced by the reduced distinguishability between increased and basic verse types, such as between types $\mathrm{A} 2 \mathrm{a}(/ \backslash / \times)$ and $\mathrm{A} 1(/ \times / \times)$, the traditional distinction between secondary-stressed and unstressed syllables would largely have been obliterated in Old Norse. Given that syllable length is hardly of crucial importance for unstressed syllables, the privileged status of the preceding drop being long or at least bimoraic in earlier metre for the composition of subtype A1s would no longer have been respected in full in Scandinavia. This weakening of the traditional convention in turn would have prompted an analogical extension of the configuration at issue, resulting in the more frequent use of the originally exceptional variant Pxpx and even the creation of the maximally deviant configuration Px...px (see Suzuki 2014: 39-40, 274-275, 775). ${ }^{15}$

In light of the quasi universality of clashing lifts in type $\mathrm{C}$, we should focus on the varied treatment of subtype A1s for determining the evolutionary trajectory of suspension of resolution in the cognate metres. In the Heliand, resolution is suspended less frequently, obviously in inverse proportion to the increased operation of resolution: a disyllabic sequence of a short stressed and an unstressed syllable is treated as a single metrical unit by default. In fornyrðislag and ljóðaháttr, suspension of resolution becomes widespread at the expense of implementation of resolution: no longer conditioned by the preceding drop that is occupied by a stressed syllable, resolution may freely be suspended after unstressed syllables as well. The disyllable in question is therefore normally measured as a succession of a lift and a drop.

\subsection{The normal drop}

While the normal drop may be aligned to a varying number of unstressed syllables, ${ }^{16}$ its relative size is controlled by the linearity-based prominence scale of metrical positions (Suzuki 1996: 167; 2004: 10; 2014: 11): the closer a given

\footnotetext{
15 As may be recalled (see Table 9 above), only the minimal configuration Pxpx is attested in Beowulf. Hence, it may be inferred that the longer configuration Px...px would have constituted a further deviation from the prototype PS\#px.

16 As argued at great length in Suzuki (2014: 210-213), the drop is ineligible for resolution as a matter of principle.
} 
drop is to the end of a verse, the less prominent it is. Accordingly, the verseinitial drop is maximal, and the verse-final one minimal, in prominence, as is measured in stochastic terms by the differing numbers of syllables realised in each position. The overall graded distinction of drops is commonly observed within all of the individual metres under consideration. In cross-dialectal terms, however, the size of corresponding drops varies substantially. For ease of comparison, we may focus on the linguistic alignment of the verse-initial drop (types $B[\times / \times /]$ and $C[\times / / \times]$, exemplified in [5] and [10] above; Table 11 ) and the verse-final one (type A1 $[/ \times / \times]$, exemplified in [5] above; Table 12 ), and determine their relative prominence in the five cognate metres. ${ }^{17}$

As should be obvious at first glance, the five metres seem to be divided into three groups in regard to the probability with which the minimal material (i.e., the monosyllabic drop) occupies the verse-initial drop. In fact, this observation turns out to be statistically provable. Comparing the proportion of monosyllables to polysyllables in the verse-initial drop shows that Beowulf and ljóðaháttr do not differ significantly $(\mathrm{p}=0.260)$, nor do the Heliand and málaháttr ( $\mathrm{p}=0.583)$; otherwise, any two of the five metres involved are distinguished with a p-value of less than 0.001 . We may accordingly posit the following scale for the relative size of the verse-initial lift: Heliand/málaháttr > Beowulflljóðaháttr $>$ fornyrðislag.

The two pairs of similar metres in turn can be differentiated on the basis of the varying incidence of the two minimal realisations put together, that is, the proportion of the monosyllabic and disyllabic verse-initial drop to the longer one. Specifically, the Heliand and ljóðaháttr are more likely to have the position in question realised in larger size than málaháttr and Beowulf, respectively, with a p-value of less than 0.001 .

By combining the two complementary criteria, then, we may be allowed to postulate the following scale in order of decreasing size of the verse-initial drop:

(11) Heliand > málaháttr > ljóðaháttr > Beowulf > fornyrðislag

Turning to the differing ways in which the verse-final drop is realised in prosodic terms, we are struck by the null manifestation (catalexis) in fornyrðislag and ljóðaháttr on the one hand (12), and the disyllabic instantiation in the Heliand on the other (13).

17 Since anacrusis differs widely from metre to metre in its metrical status - underlying versus derived - and frequency of usage, it cannot serve as a representative marker of the verse-initial drop. 


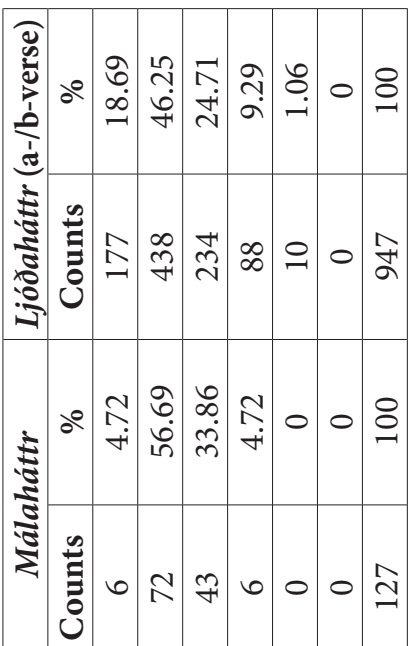

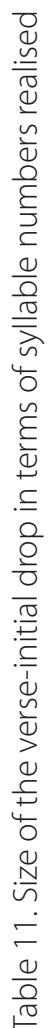

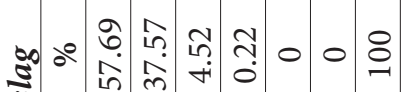

:30

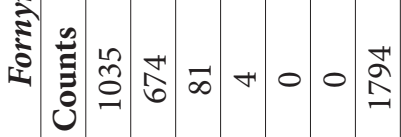

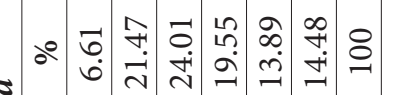

गิ

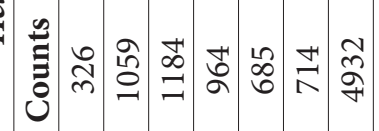

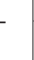

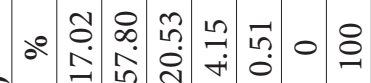

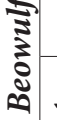

仓̇



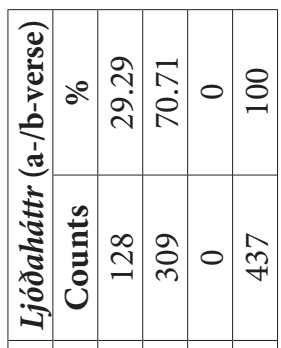

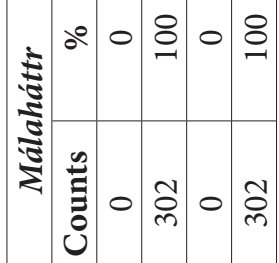

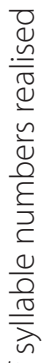



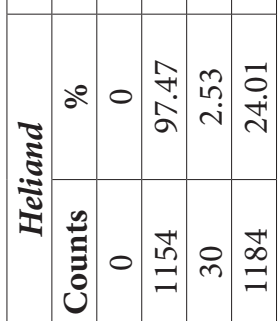

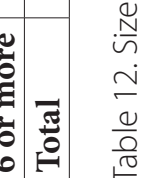


(12) $R p 11.8$ prungin dœegr 'a full day' [PxP] (type A1-; fornyrðislag) HH II 8.1 Pat vann næst nýs 'That fought most recently' [xxPP] (type C-; fornyrðislag)

Hav 152.4 brennrat svá breitt 'it does not burn so widely' [PxxP] (type A1-; ljóðaháttr)

Ls 11.4 nema sá einn áss 'except for that one god' [xxxPP] (type C-; ljóðaháttr)

(13) Hel 319a thiornun thînaro 'your young wife' [PxPxx] (type A1) $\mathrm{Hel}$ 4741a that he im thero costondero 'that he of the tempters' xxxxxPXxx] (type C)

The zero and the disyllabic realisation, respectively, are North Germanic and Old Saxon metrical innovations which are linguistically motivated. Of paramount importance, these deviations are matters of metrical alignment on the surface, rather than of underlying arrangement of differing numbers of metrical positions, as argued at length in Suzuki (2004: 73-75, 123-124) and Suzuki (2014: 185-201). The occurrences of the smaller or longer variants make a significant difference on statistical grounds: $\mathrm{p}<0.001$ between the Heliand and Beowulf; $\mathrm{p}=0.002$ between the Heliand and málaháttr; $\mathrm{p}<0.001$ between each of Beowulf/málaháttr on the one hand and each of fornyrðislag/ljóðaháttr on the other. By contrast, Beowulf and málaháttr strictly conform to the absolute limitation in alignment to monosyllables $(\mathrm{p}=1)$. Moreover, fornyrðislag and ljóðaháttr differ in the likelihood of catalexis: ljóðaháttr is more likely to be affected by the process $(\mathrm{p}<0.001)$. Overall, then, we are led to posit the scaled distinction in order of decreasing size of the verse-final drop, as follows:

(14) Heliand > Beowulf/málaháttr > fornyrðislag > ljóðaháttr

This scalar distinction proves to be essentially the same as that for resolvability (6): the Heliand is maximally prominent, and ljóðaháttr minimally so, in the verse-final drop as in the lift.

What deserves particular notice is the apparent discrepancy between the two scales, the one for the verse-initial drop (11), the other for the verse-final one (14). Given that the relative prominence of metrical positions is coordinated by the linearity-based scale on the whole, we would expect them to be analogously organised: the expansion or reduction in the range of alignment would be implemented in harmony throughout the verse. The deviation from the predicted parallelism in scalar arrangement is embodied by two metres, málaháttr and ljóðaháttr. Excluding these deviant metres from the scales 
would result in their perfect match: Heliand $>$ Beowulf $>$ fornyrðislag. We are required then to provide explanations of why málaháttr and ljóðaháttr, rather than the other metres, apparently fail to display well-patterned behaviour.

Málaháttr emerges through the replacement of the four-position principle by the five-position counterpart, as treated in section 2.1 above. As a consequence of this reorganisation, the verse-initial drop is redoubled, so that types $\mathrm{B}$ and $\mathrm{C}$ are restructured as types $\mathrm{B}^{\star}(\times \times / \times /)$ and $\mathrm{C}^{\star}(\times \times / / \times$; Suzuki 2014: $453-458)$. In this light, the larger size of the verse-initial drop must be ascribed to the doubling of an underlying metrical position, rather than the alignment of a single position to a longer stretch of unstressed syllables as in the Heliand. Therefore, málaháttr should be removed from the scale (11), which must be revised as follows:

(15) Heliand > ljóðaháttr > Beowulf $>$ fornyrðislag.

The scale for the verse-final drop is no less affected by the establishment of the five-position principle. Catalexis is found to be no longer compatible with the novel principle. In the earlier metre (fornyrðislag), the zero realisation of the verse-final drop requires expansion in alignment of the first one as a compensation for the reduced prominence due to catalexis (Suzuki 2014: $77-80,108)$. Given this inherited practice, the hypothetical catalectic variant of type $\mathrm{Al}^{\star}(/ \times \times / \times$, the five-position counterpart of type A1) would hardly be distinguished from type A1- $(/ \times /[\times] ;[\times]=$ unrealised verse-final drop $)$ with the enlarged first drop in terms of surface realisations. Moreover, it would scarcely be practical to differentiate the new configuration (type $\mathrm{A}^{*}{ }^{*}$ ) from type $\mathrm{A} 1^{\star}$ by a further expansion of the available drop. Accordingly, málaháttr is determined as ineligible for catalexis on structural grounds, which explains why this metre is distinguished from the other two Norse cognates on this parameter, as represented in the scale (14).

As far as ljóðaháttr is concerned, the a-verse and the b-verse are polarised in their organisation (as mentioned in section 2.1 above; for details, see Suzuki 2014: 645-652). The two verses are structured divergently by the binary-opposed verse-initial and verse-final positions, / for the a-verse and $\times$ for the $b$-verse in initial position, and conversely $\times$ for the a-verse and / for the b-verse in final position. Furthermore, the a-verse tends to be composed in shorter size than the b-verse: two-position verses - double catalectic verses (Suzuki 2014: 643) - are limited to the a-verse. In contrast, five-position verses are more strongly represented in the b-verse: anacrustic variants are more likely to occur in the b-verse, as is type $\mathrm{D}^{*}$ relative to type $\mathrm{D}$ (Suzuki 2014: 648-649). In this light, it is no wonder that catalectic verses appear in the 
a-verse with a significantly greater frequency than in the b-verse. By opposition, the b-verse tends to be extended, particularly in the verse-initial drop, the privileged position that is maximal in its potential range of alignment. Accordingly, on the one side the scale for the verse-final drop largely concerns the a-verse, and on the other the one for the verse-initial drop primarily controls the b-verse. The two scales thus relate to the two divergently composed verses, rather than the integrated pair of the a-verse and the b-verse as in the other metres, in which the two constituent verses of a line are organised in parallel fashion. The mismatch of the two scales in ljóðaháttr is therefore derived as a matter of course from the polar opposition between the two verses in metrical organisation.

Having provided principled accounts of the unique ways in which málaháttr and ljóðaháttr organise verse composition, we can maintain the three-way graded distinction in linguistic alignment of the drop in most general terms, as follows:

(16) Heliand > Beowulf $>$ fornyrðislag

In this way, the drop is consistently realised in order of decreasing size in Heliand, Beowulf, and fornyrðislag.

\subsection{The heavy drop}

Where the heavy drop is constitutive of an increased verse type through a direct opposition to the normal counterpart (see section 2.2 above), it is typically occupied by a secondary-stressed syllable, long (S) or short (s), and occasionally by a primary-stressed one, long $(\mathrm{P})$ or short $(\mathrm{p})$. The second position of type $\mathrm{E}(/ \backslash \times /)$, however, is unique in that it is exclusively aligned to a heavy drop: there is no legitimate configuration $/ \times x /$ that would be characterised as a derivational basis for the extant type E. In the absence of the otherwise basic configuration, the second position of type E may also be filled by a syllable lacking a lexical stress, preferably a long medial syllable -Xdue to its closer proximity to lexically stressed syllables in terms of inherent prominence. Because of such a structurally unique status, the second position of type $\mathrm{E}$ - with or without anacrusis - is loaded with a maximal potential for variation in linguistic alignment. Given this maximal variability and also the ubiquitous presence of this type in all of the cognate metres under examination here, we may concentrate on type $\mathrm{E}$ in illustrating the varying ways in which the heavy drop is aligned to linguistic material (Table 13). 
First, resolution occurs only in the West Germanic metres (Beowulf and the Heliand), as exemplified below:

(17) Beo 2661b wìgheafolan bær 'helmet carried' [PsxxP] Hel 3399a uuârsaguno uuord 'the prophets' words' [PsxxP]

The two metres differ, however, in the incidence of resolution: in comparison with the default alignment to a long syllable, the Heliand is more likely to undergo resolution than Beowulf, with a p-value of 0.005 .

Second, the heavy drop of type E may be occupied by a short syllable in Beowulf, the Heliand, and ljóðaháttr (a-/b-verse), as follows:

(18) Beo 623b bēaghroden cwēn 'ring-adorned queen' [PsxP]

Hel 1742a uuînberi uuesan 'wine-grapes be' [Psxpx]

$H H v 25.5$ hraunbúa verstr 'the worst of rock-dwellers' ${ }^{18}$ [PsxP]

While the proportion of short to long syllables does not differ definitely between the two West Germanic metres ( $p=0.090)$, either is significantly distinguished from ljóðaháttr ( $\mathrm{p}=0.010$ between Beowulf and ljóðaháttr; $\mathrm{p}<0.001$ between the Heliand and ljóðaháttr). Ljóðaháttr is thus most likely to realise a short syllable as the second position of type E among the three metres involved. Furthermore, the complete absence in fornyrðislag of a short syllable as a realisation of the first drop of type E lacks statistical significance, in light of p-values of 0.224 as against Beowulf and of 1 as against the Heliand (compare Suzuki 2014: 138). Rather, given a significant difference between fornyrðislag and ljóðaháttr in this respect $(\mathrm{p}=0.002)$, ljóðaháttr can exclusively be distinguished by the higher likelihood of the position in question being filled by a short syllable.

Third, only Beowulf and the Heliand may align the position at issue to a syllable without a lexical stress - a long medial one (-X-) for the most part, as represented below:

(19) Beo 50a murnende mōd 'morning mind' [PXxP]

Hel 2259a uualdandes uuord 'the Ruler's word' [PXxP]

By contrast, the same configuration PXx...P is scanned as type A1-, the catalectic variant of type A1, in the Norse metres (Suzuki 2014: 145-148).

\footnotetext{
18 It should be noted that a long vowel is shortened when immediately preceding another vowel (Bugge, Sievers 1891; Sievers 1893: 58).
} 
Table 13. Linguistic realisations of the heavy drop of type E according to syllable shape

\begin{tabular}{|l|l|l|l|l|}
\hline Syllable & Long & Resolved & Short & Total \\
\hline Beowulf & $398(95.90 \%)$ & $7(1.69 \%)$ & $10(2.41 \%)$ & $415(100 \%)$ \\
\hline Heliand & $402(93.93 \%)$ & $23(5.37 \%)$ & $3(0.70 \%)$ & $428(100 \%)$ \\
\hline Fornyrðislag & $103(100 \%)$ & $0(0 \%)$ & $0(0 \%)$ & $103(100 \%)$ \\
\hline Ljóðaháttr (a-/b-verse) & $54(90.00 \%)$ & $0(0 \%)$ & $6(10.00 \%)$ & $60(100 \%)$ \\
\hline
\end{tabular}

\section{Conclusion}

The principle of four metrical positions per verse regulates verse composition in Beowulf, the Heliand, fornyrðislag, and ljóðaháttr, while málaháttr is predicated on the five-position one. The four-position principle works with a maximal strictness in Beowulf, and to a slightly lesser extent in fornyrðislag, whereas it allows for a wider range of deviations in verse size in the Heliand and ljóaháttr.

In regard to metrical-linguistic alignment, and with exclusive reference to the three metres that are organised largely on the analogous basis, namely, Beowulf, the Heliand, and fornyrdislag, we may postulate the following scale for the decreasing likelihood of resolution, the increasing likelihood of suspending resolution, and the decreasing size of the drop:

(20) Heliand > Beowulf $>$ fornyrðislag

In other words, given metrical positions are more likely to be aligned to more prominent linguistic material in the Heliand; and conversely, they are most likely to be realised in the least salient form in fornyrðislag. ${ }^{19}$

\section{References}

Anderson, Stephen R. 2011. Clitics. In: Oostendorp, Marc van; Ewen, Colin J.; Hume, Elizabeth; Rice, Keren (eds.) 2011. The Blackwell Companion to Phonology, Vol. IV: Phonological Interfaces. Malden, Mass.: Wiley-Blackwell, 2002-2018.

Aroui, Jean-Louis; Arleo, Andy 2009. Towards a Typology of Poetic Forms: From Language to Metrics and Beyond. Amsterdam: Benjamins.

19 Thanks are due to two anonymous reviewers for their useful comments and suggestions on an earlier version of this paper. 
Axboe, Morten 2004. Die Goldbrakteaten der Völkerwanderungszeit: Herstellungsprobleme und Chronologie (Ergänzungsbände zum Reallexikon der Germanischen Altertumskunde 38). Berlin: De Gruyter.

Behaghel, Otto; Taeger, Burkhard (eds.) 1996. Heliand und Genesis. 10th edn. Tübingen: Niemeyer.

Behr, Charlotte 2011. Forschungsgeschichte. In: Heizmann, Wilhelm; Axboe, Morten (eds.), Die Goldbrakteaten der Völkerwanderungszeit: Auswertung und Neufunde (Ergänzungsbände zum Reallexikon der Germanischen Altertumskunde 40). Berlin: De Gruyter, 153-229.

Bugge, Sophus; Sievers, Eduard 1891. Vocalverkürzung im Altnordischen. In: Beiträge zur Geschichte der deutschen Sprache und Literatur 15, 391-411.

Cable, Thomas 1974. The Meter and Melody of Beowulf. Urbana: University of Illinois Press.

Cable, Thomas 1991. The English Alliterative Tradition. Philadelphia: University of Pennsylvania Press.

Connell, Bruce 2011. Downstep. In: Oostendorp et al., 824-847.

Fabb, Nigel; Halle, Morris 2008. Meter in Poetry: A New Theory. New York: Cambridge University Press.

Fulk, R. D.; Bjork, Robert E.; Niles, John D. (eds.) 2008. Klaeber's Beowulf and the Fight at Finnsburg, 4th edn. Based on the third edition of Beowulf and the Fight at Finnsburg, ed. by Fr. Klaeber (1950). Toronto: University of Toronto Press.

Gussenhoven, Carlos 2004. The Phonology of Tone and Intonation. Cambridge: Cambridge University Press.

Hayes, Bruce 1989. The prosodic hierarchy in meter. In: Kiparsky, Paul; Youmans, Gilbert (eds.), Rhythm and Meter. San Diego: Academic Press, 201-260.

Lotz, John. 1960. Metric typology. In: Sebeok, Thomas A. (ed.), Style in Language. Cambridge, Mass.: MIT Press, 135-148.

Neckel, Gustav; Kuhn, Hans 1983. Edda: Die Lieder des Codex Regius nebst verwandten Denkmälern. 5th edn. Heidelberg: Winter.

Nespor, Marina; Vogel, Irene 1986. Prosodic Phonology. Dordrecht: Foris.

Noreen, Adolf 1970. Altnordische Grammatik I. 5th edn. Tübingen: Niemeyer.

Odden, David 1986. On the role of the obligatory contour principle in phonological theory. In: Language 62, 353-383. 
Oostendorp, Marc van; Ewen, Colin J.; Hume, Elizabeth; Rice, Keren (eds.) 2011. The Blackwell Companion to Phonology, Vol. II, Suprasegmental and Prosodic Phonology. Malden, Mass.: Wiley-Blackwell.

Revithiadou, Anthi 2011. The phonological word. In: Oostendorp et al., 1204-1227.

Russom, Geoffrey 1998. Beowulf and Old Germanic Metre. Cambridge: Cambridge University Press.

Sievers, Eduard 1893. Altgermanische Metrik. Halle: Niemeyer.

Suzuki, Seiichi 1996. The Metrical Organization of Beowulf: Prototype and Isomorphism (Trends in Linguistics. Studies and Monographs 95). Berlin: De Gruyter; repr., 2011.

Suzuki, Seiichi 2004. The Metre of Old Saxon Poetry: The Remaking of Alliterative Tradition. Cambridge: Brewer.

Suzuki, Seiichi 2008. Anglo-Saxon Button Brooches: Typology, Genealogy, Chronology (Anglo-Saxon Studies 10). Woodbridge: Boydell.

Suzuki, Seiichi 2014. The Meters of Old Norse Eddic Poetry: Common Germanic Inheritance and North Germanic Innovation (Ergänzungsbände zum Reallexikon der Germanischen Altertumskunde 86). Berlin: De Gruyter.

Wimsatt, William K. (ed.) 1972. Versification: Major Language Types. New York: Modern Language Association. 